address, he showed how the institute had originated, and he sketched its career; he then dealt with the position of the man of science in regard to humanity and the world's progress. $\mathrm{He}$ said that it is true that man does not live and move and have his being at the dictates of science, but it is to science that civilisation owes its present position, and in the thickly populated centres man's very existence depends upon the progress of science. The works of science are so wrapped up in the ordinary man's daily life that he not only does not feel grateful to the scientific man, but frequently ignores his very existence. The man in the street, in fact, although he may be well informed in other directions, forgets, or never knows, that applied science must be based upon discoveries in pure science, which at first may appear to have no importance whatever for the human race. The progress of the world depends upon the number, the quality, and the zeal of the men of science. They are the ultimate makers of the people's wealth and the rulers of the people's destinies; and they must always be highly trained and enthusiastic in their work.

The Mayor of Christchurch, in a short address, congratulated the institute, and also congratulated Dr. Cockayne on being elected a Fellow of the Royal Society. Mr. G. M. Thomson, as the representative of the Parliament of New Zealand, read congratulatory messages from the Prime Minister of the Dominion and from the Hon. R. H. Rhodes to the institute and to Dr. Cockayne as the winner of the Hector medal for his researches in botany. Mr. Thomson added that he had been asked to present to Dr. Cockayne this first Hector medal, struck in honour of the late Sir James Hector. The medal had not arrived in the Dominion, and could not be handed to the recipient just then, but it carried with it a grant to help in the recipient's future work. Dr. Cockayne's researches had cost him large sums of money, and he had great pleasure in asking that gentleman to accept a sum which would help him in the great work he still had in hand.

Dr. Cockayne returned thanks, and after other addresses had been given, the gathering was brought to an end.

\section{PLAICE FISHERIES OF THE NORTH SEA.}

THE tenth meeting of the International Council for the Study of the Sea was held at Copenhagen in April last, and the Procès-Verbaux have recently been published. The most important subject considered was the general report on the plaice fisheries of the North Sea, which is being prepared by Prof. Heincke, of Heligoland. Only the first section of this report was, however, ready at the time of the meeting, and it was decided that another meeting should take place at the end of September for the further consideration of the matter. The section of the report laid before the meeting by Prof. Heincke in April was based chiefly on the special market statistics of plaice landed, the greater part of the material being derived from English ports. The results of the work of the special steamers remain to be considered.

From an economic point of view the study of the plaice question is undoubtedly the most important work which the council has undertaken, and it is to be regretted that such great delay has occurred in the preparation of the report. Prof. Heincke cannot be blamed for this delay, which seems to have been due to faulty organisation on the part of the council, and to a want of appreciation of the magnitude of the task. The work might well have occupied the entire time and energy of one man with a staff of trained assistants under him, and it was clearly impossible that it could be carried out within a reasonable time, in addition to his other duties, by the director of the Heligoland Biological Station. If some of the money which has been spent on the organisation and formal administration of the Council and on the less important parts of the programme had been employed to enable Prof. Heincke to devote his whole time and energy to the task and to obtain adequate assistance in doing the detailed work, the position at the present time would have been much more satisfactory.

\section{THE PLASTIC ART OF PALAOLITHIC MAN.}

$W^{E}$ learn from The Times of October $3 \mathrm{I}$ that Count Begouen, the well-known investigator of prehistoric archæology, has made a remarkable discovery in the cave known as Tus Ditboubert, in the district of MontesquieuAventès (Ariège), where three months ago he found mural paintings of animals, presumably of Aurignacian age. On October 1o the Count and his son broke through a mass of stalactites, and in the new gallery thus exposed found two clay figures, respectively 26 in. and 30 in. long, representing a bull and cow bison. They appear to have been attached originally to a rock, as one side is rough while the other is completely modelled. They are nearly perfect; the only damage that they had received was that one of the horns of the female bison and its tail had been broken off; the tail was, however, found on the floor of the cave. A third small clay figure was also found, but it was so roughly modelled as to make it impossible to say what it represents.

In passing through the galleries the explorers found many footprints of bears and human beings. In one of the galleries, where there was a number of otherwise indistinguishable marks on the floor, some fifty imprints of human heels were discovered, and Count Begouen, in his communication to the Academy of Inscriptions of Paris on October 30, suggested that these may represent traces of ritual observances or dances similar to those which have been oberved among the savage tribes of the present day in Australia and Africa.

This is the first time clay figures of Palæolithic date have been discovered, and it affords one more example of the wonderful finds that have been yielded by the French caves. A very large number

NO. 2245, VOL. 90] 
of engravings and carvings of animals on bone and ivory have been found, as well as engravings and paintings on the walls of caves, in France and Spain; mural carvings in low relief are also known, outlines of bison traced on the clay fioor occur in a cave at Niaux, and now clay figurines have come to light.

There can be little doubt that many of these works of art had what we now term a magicoreligious significance. Artists are not likely to have carved, engraved, painted, or modelled in the black recesses of caves merely for the joy of expression, since few of their fellow-tribesmen would see their works of art, and then but imperfectly. The only adequatc solution of the problem seems to be that these delineations and representations had a significance which was at the same time practical and religious, and it is possible that some at least of them were made for the purpose of enabling their originals to be captured, or may be, as in the case of ccrtain Australian ceremonies, to increase their numbers; in either case, their significance would be more utilitarian than asthetic.

\section{NOTES.}

Wr regret to have to announce the death of $\mathrm{Mr}$. Henry (iroves, at his residence at Clapham, on Saturday evening, November 2, at fifty-seven years of age, after an illness extending over many months. In conjunction with his brother James, Mr. Groves was widely known as possessed of exceptional acquaintance with the small but difficult group of the Characeæ, and the opinion of the brothers "H. and J. Groves" was constantiy sought by botanists of all nations. It is understood that a volume on the British species, for issue by the Ray Society, is practically ready for the press. The most conspicuous task in which both brothers engaged was the editing of the ninth edition of Babington's "Manual of British Botany," which was in many respects remodelled, and came out in 1904. Mr. Henry Groves had served on the council of the Linnean Society some ycars since; at the time of his death he was again a councillor, and in certain questions he took a leading part. His death removes a loyal and devoted worker, whose place will not be easily filled.

Dr. Benjamin Boss, son of the late Prof. Lewis Buss, director of the Dudley Observatory, Albany, N.Y., has been appointed acting-director of that institution.

M. Emile Boutrovx was on October 3 i elected a member of the French Academy. The eminent French philosopher is honorary professor of modern philosophy at the Sorbonne, and director of the "Fondation Thiers," a residential college for post-graduate study. $\mathrm{He}$ is known as the author of numerous important philosophical works.

The eighty-seventh Christmas course of juvenile lectures, founded at the Royal Institution in 1826 by Michael Faraday, will be delivered this year by Sir James Dewar, F.R.S., Fullerian professor of chem- istry, his title being "Christmas Lecture Epilogues." The lectures will be experimentally illustrated, and the dates and subjects are as follows :-Saturday, December 28, "Alcherny" ; December 31, "Atoms "; January 2, 1913, "Light"; January 4, "Clouds"; January 7, "Meteorites "; January 9, "Frozen Worlds."

Owing to bad weather, the illuminated night flying and firework display that was to be held at the London Aerodrome, Hendon, on Tuesday, November 5, has been postponed until Saturday next, November 9 . Special exhibition flights, speed and altitude tests will take place from 2.30 p.m. until dusk, and the illuminated night fiying and firework display will be in progress from 7.30 p.m. until io p.m.

$T_{\text {HE }}$ series of lectures which the Selborne Society annually arranges will begin on November 11 , when Lord Montagu of Beaulieu will preside, and Mr. Fred Enock will deal with "Fairy Flies and their Hosts." Among the subjects of other lectures are :- "Minor Planets," by Dr. A. C. D. Crommelin (January 20, I913); "Fibres and Fibre Lore," by Mr. C. Ainsworth Mitchell (February I7); and "Byways in Biology," by Mr. James Saunders (March 3). The special children's lecture will be given by $\mathrm{Mr}$. Spencer Fletcher on "Dew, Hoar-frost, and Clouds" (January 9).

THE death is announced, at the age of seventy-two, of Dr. William Willard Daniells, the founder of the study of chemistry at the University of Wisconsin. In 1868 he was appointed to a chair in that institution, and established its first chemical laboratory, giving daily instruction to one student, and using an old carpenter's bench in the basement. Dr. Daniells continued in active work as the head of the chemistry department until 1907, when he became professor emeritus. $\mathrm{He}$ also conducted the weather bureau at the University, until this work was taken over by the U.S. Government. From 1872 to 1876 he was chemist to the Wisconsin State Geological Survey.

THE Weber-Parkes prize (of 150 guineas and a silver medal), founded in 1895 by Sir Hermann Weber in memory of the late Dr. E. A. Parkes, and awarded every third year to the author of the best essay "upon some subject connected with the etiology, prevention, pathology, or treatment of tuberculosis, especially in reference to pulmonary consumption in man," has been awarded by the Royal College of Physicians to Mr. J. A. D. Radcliffe, pathologist to the King Edward VII. Sanatorium, Midhurst. The subject of the next essay, to be adjudicated upon in 1915 , is an original research on the treatment of pulmonary tuberculosis with substances which are especially antagonistic to the specific organism and its products. This work must have been chiefly carried on since the year 1911. The following lectures will be given at the Royal College of Physicians during November:- Dr. Raymond Crawfurd will deliver the FitzPatrick lectures on "The History of Medicine" on November 7, 12, 14. and 19, the subject being "Echoes of Pestilence in Literature and Art"; the Horace Dobell lecture by Dr. C. J. Martin, on "Insect Porters of Bacterial Infection," will be delivered on November 21 .

$$
\text { NO. 2245, VOL. 9o] }
$$

